\title{
Capacitance Measurements of Regulated Exocytosis in Mouse Taste Cells
}

\author{
Aurelie Vandenbeuch, ${ }^{1,2}$ Robert Zorec, ${ }^{3,4}$ and Sue C. Kinnamon ${ }^{1,2}$ \\ ${ }^{1}$ Department of Otolaryngology and ${ }^{2}$ Rocky Mountain Taste and Smell Center, University of Colorado, Denver, Aurora, Colorado 80045, and ${ }^{3}$ Laboratory of \\ Neuroendocrinology-Molecular Cell Physiology, Institute of Pathophysiology, Faculty of Medicine, University of Ljubljana, and ${ }^{4}$ Laboratory of Cell \\ Engineering, Celica, Biomedical Center, 1000 Ljubljana, Slovenia
}

Exocytosis, consisting of the merger of vesicle and plasma membrane, is a common mechanism used by different types of nucleated cells to release their vesicular contents. Taste cells possess vesicles containing various neurotransmitters to communicate with adjacent taste cells and afferent nerve fibers. However, whether these vesicles engage in exocytosis on a stimulus is not known. Since vesicle membrane merger with the plasma membrane is reflected in plasma membrane area fluctuations, we measured membrane capacitance $\left(C_{\mathrm{m}}\right)$, a parameter linearly related to membrane surface area. To investigate whether taste cells undergo regulated exocytosis, we used the compensated tight-seal whole-cell recording technique to monitor depolarization-induced changes in $C_{\mathrm{m}}$ in the different types of taste cells. To identify taste cell types, mice expressing green fluorescent protein from the TRPM5 promoter or from the GAD67 promoter were used to discriminate type II and type III taste cells, respectively. Moreover, the cell types were also identified by monitoring their voltage-current properties. The results demonstrate that only type III taste cells show significant depolarization-induced increases in $C_{\mathrm{m}}$, which were correlated to the voltage-activated calcium currents. The results suggest that type III, but neither type II nor type I cells exhibit depolarization-induced regulated exocytosis to release transmitter and activate gustatory afferent nerve fibers.

\section{Introduction}

Taste buds are the transducing elements of gustatory sensation. Each taste bud houses between 50 and 100 taste cells, which extend from the basal lamina to the surface of the epithelium, where their apical processes protrude through a taste pore and encounter taste stimuli in the oral cavity. The basolateral regions of taste cells communicate sensory information to other taste cells and to gustatory nerve fibers, which course throughout the taste bud. Considerable progress has been made in identifying the taste receptor proteins and downstream signaling effectors involved in taste transduction (Chandrashekar et al., 2006). However, much less is understood about how taste information is communicated from taste cells to afferent nerve fibers.

Taste buds comprise three types of cells, based on morphological, immunocytochemical, and functional criteria. Type I cells, called "glial-like" cells, express enzymes for inactivation and uptake of neurotransmitters (Lawton et al., 2000; Bartel et al., 2006)

\footnotetext{
Received March 26, 2010; revised Aug. 30, 2010; accepted Sept. 7, 2010.

This work was supported by Bilateral Grant BI-US/08-10-034 (R.Z., S.C.K.); R.Z. is supported by Grants P3-3100381, J3-0133, J3-0031, and J3-9417 from the Research Agency of the Republic of Slovenia. S.C.K. is supported by National Institutes of Health Grants DC000766 and DC007495. We thank Dr. William Betz for the use of the SWAM IIC amplifier, Dr. Robert Margolskee for the TrpM5-GFP mice, and Catherine Anderson and Daniel Sanculi for technical assistance. We also thank Dr. Jack Kinnamon for helpful discussions and Drs. Thomas Finger and Katie Rennie for comments on this manuscript.

Correspondence should be addressed to either of the following: Robert Zorec, Laboratory of Cell Engineering, Celica, Biomedical Center, Technology Park 24, 1000 Ljubljana, Slovenia, E-mail: robert.zorec@mf.uni-lj.si (for membrane capacitance measurements); or Sue C. Kinnamon, Department of Otolaryngology, University of Colorado Denver, 12700 East 19th Avenue, Mail Stop 8606,Aurora, C0 80045, E-mail: sue.kinnamon@ucdenver.edu (for taste cells).

DOI:10.1523/JNEUROSCI.1570-10.2010
}

Copyright $\odot 2010$ the authors $\quad 0270-6474 / 10 / 3014695-07 \$ 15.00 / 0$ and are generally presumed to have a support function. Type I cells possess only voltage-gated outward currents (Medler et al., 2003; Romanov and Kolesnikov, 2006) and do not form synaptic contacts with afferent nerve fibers. Type II taste cells, also called "receptor" cells, possess the taste receptors and signaling effectors for bitter, sweet, and umami stimuli (Zhang et al., 2003; Clapp et al., 2004). These cells possess voltage-gated $\mathrm{Na}^{+}$and $\mathrm{K}^{+}$currents (Medler et al., 2003; Romanov and Kolesnikov, 2006) and generate action potentials to taste stimuli (Yoshida et al., 2006). Type II cells release ATP as a transmitter to activate purinergic receptors on afferent nerve fibers (Finger et al., 2005). These cells associate with nerve fibers, but lack voltage-gated $\mathrm{Ca}^{2+}$ channels and the typical presynaptic specializations (Clapp et al., 2006; DeFazio et al., 2006). ATP is released through gap junction hemichannels (Y. J. Huang et al., 2007; Romanov et al., 2007; Dando and Roper, 2009). Recent data suggest, however, that type II cells also express vesicular transporters for ATP (Iwatsuki et al., 2009), suggesting ATP may also be released by vesicular mechanisms. Type III taste cells, called "synaptic" cells, form conventional synapses with afferent nerve fibers (Yang et al., 2000; Yee et al., 2001). These cells are highly excitable with voltage-gated $\mathrm{Na}^{+}, \mathrm{K}^{+}$, and $\mathrm{Ca}^{2+}$ currents, and release serotonin and noradrenalin on membrane depolarization (Y. A. Huang et al., 2008) or ATP released from type II taste cells (Y. J. Huang et al., 2005; Y. A. Huang et al., 2009). Type III taste cells express glutamic acid decarboxylase isoform GAD67, suggesting GABA also may be released as a neurotransmitter (DeFazio et al., 2006).

Fusion of vesicle membrane with the plasma membrane causes an increase in membrane surface area that can be measured with whole-cell patch clamp as changes in membrane ca- 
pacitance $\left(C_{\mathrm{m}}\right)$ (Neher and Marty, 1982). We report the first high-resolution $C_{\mathrm{m}}$ measurements of regulated exocytosis in taste cells. Using transgenic mice expressing green fluorescent protein (GFP) from cell type-specific promoters, we report that type III taste cells exhibit depolarizationinduced increases in $C_{\mathrm{m}}$, which are correlated with voltage-activated calcium currents, suggesting that transmitter release from these cells is mediated by $\mathrm{Ca}^{2+}$ dependent vesicular mechanisms.

\section{Materials and Methods}

Mice and taste cell isolation. Breeding pairs of GAD67-GFP mice, obtained from The Jackson Laboratory (stock 007677), were bred and used to identify type III taste cells. Approximately $75 \%$ of type III taste cells express GAD67 (DeFazio et al., 2006). TrpM5-GFP mice were bred and used to identify type II taste cells, since TrpM5 is exclusively expressed in type II taste cells (Clapp et al., 2006). These mice were a generous gift from Dr. Robert Margolskee (Mt. Sinai Medical School, New York, NY; now at Monell Chemical Senses Center, Philadelphia, PA). TrpM5 is the $\mathrm{Ca}^{2+}$-activated monovalent-

selective cation channel required for bitter, sweet, and umami taste transduction (Pérez et al., 2002; Zhang et al., 2003) and is a convenient marker for type II taste cells. In this study, we used only GAD67-GFP-positive taste cells to identify type III cells, since these cells represent only $\sim 15 \%$ of the cells in the taste bud. For type II cells, which make up $\sim 35 \%$ of the taste bud, we used both TrpM5-GFP-positive cells and unlabeled cells showing voltage-gated $\mathrm{Na}^{+}$and $\mathrm{K}^{+}$currents, but no voltage-gated $\mathrm{Ca}^{2+}$ current (Vandenbeuch and Kinnamon, 2008). Mice of both genders were used for these studies.

Circumvallate taste cells were isolated by a method adapted from Béhé et al. (1990). Briefly, adult mice were killed by $\mathrm{CO}_{2}$ inhalation and cervical dislocation. The tongue was removed and $\sim 0.2 \mathrm{ml}$ of an enzyme mixture was injected between the epithelium and the underlying muscle. The enzyme mixture consists of $1 \mathrm{mg} / \mathrm{ml}$ collagenase B (Roche), $3 \mathrm{mg} / \mathrm{ml}$ dispase II (Roche), and $1 \mathrm{mg} / \mathrm{ml}$ trypsin inhibitor (Sigma-Aldrich) dissolved in $1 \mathrm{mg} / \mathrm{ml}$ Tyrode's. In some cases, $0.05 \mathrm{mg} / \mathrm{ml}$ elastase (Roche) was added to the enzyme mixture to improve the ability to obtain seals with the membrane. The tongue was bubbled in oxygenated $\mathrm{Ca}^{2+}$ / $\mathrm{Mg}^{2+}$-free Tyrode's containing BAPTA (2 mm; Invitrogen) for $45 \mathrm{~min}$, or until the epithelium containing the taste buds could be gently separated from the underlying connective tissue. Individual taste cells and isolated taste buds were removed by gentle suction applied by mouth and plated onto polylysine-coated coverslips affixed to perfusion chambers (RF-20; Warner Instruments). In general, isolated taste cells remained viable for up to several hours after isolation. However, during recording, $\mathrm{Ca}^{2+}$ currents in some cells tended to run down quickly, allowing us to test only a few solutions on each cell. Taste cells were viewed with an Olympus IX71 inverted microscope equipped with differential interference contrast optics and epifluorescence. All procedures were approved by the University of Colorado, Denver, Institutional Animal Care and Use Committee.

Solutions. The bath contained Tyrode's saline solution, consisting of $10 \mathrm{~mm}$ HEPES/NaOH, pH 7.4, 10 mм D-glucose, 1 mm Na-pyruvate, 140 $\mathrm{mm} \mathrm{NaCl}, 4 \mathrm{~mm} \mathrm{CaCl}_{2}, 1 \mathrm{~mm} \mathrm{MgCl}$, and $5 \mathrm{~mm} \mathrm{KCl}$. Barium Tyrode's (for isolation of $\mathrm{Ca}^{2+}$ currents) contained $136 \mathrm{~mm}$ tetraethylammonium, 10 $\mathrm{mm} \mathrm{BaCl}_{2}, 1 \mathrm{~mm} \mathrm{MgCl} 2,10 \mathrm{~mm}$ HEPES/NaOH, pH 7.4, 10 mm D-glucose, $1 \mathrm{~mm} \mathrm{Na}$-pyruvate, and $400 \mathrm{~nm}$ TTX. In some experiments, $0.5 \mathrm{~mm} \mathrm{CdCl}_{2}$ was added to Tyrode's to block voltage-gated $\mathrm{Ca}^{2+}$ currents (Medler et al., 2003). The intracellular pipette solution consisted of $140 \mathrm{~mm} \mathrm{KCl}, 1$ mм $\mathrm{CaCl}_{2}, 2$ mм $\mathrm{MgCl}_{2}, 10$ mм HEPES/KOH, pH 7.2, 11 mм EGTA, 2 mM ATP, and 0.4 mM GTP. In most experiments the pipette tip (only) was backfilled with $\mathrm{KF}$ solution (110 mм KF, $30 \mathrm{~mm} \mathrm{KCl,} 1 \mathrm{~mm} \mathrm{CaCl}_{2}$, 2 mM $\mathrm{MgCl}_{2}, 10 \mathrm{~mm} \mathrm{HEPES/KOH,} \mathrm{pH} \mathrm{7.2,} \mathrm{and} 11$ mм EGTA), to assist in seal formation. The prefilling of pipette solution by the KF solution did not affect either the voltage dependence of the currents or the membrane capacitance change compared with a $\mathrm{KCl}$ solution. All salts were of highest grade available (Sigma-Aldrich).

Electrophysiology and data analysis. Taste cells, whose input resistance typically exceeds $1 \mathrm{G} \Omega$ (Bigiani, 2001; Medler et al., 2003), were patch clamped and their membrane capacitance $\left(C_{\mathrm{m}}\right)$ was measured by using the compensated tight-seal whole-cell recording technique (Neher and Marty, 1982; Marty and Neher, 1983; Zorec et al., 1991). Measurements were performed with a dual-phase lock-in patch-clamp amplifier with the $1 \mathrm{G} \Omega$ resistor in the head-stage (SWAM IIC; Celica). A $1591 \mathrm{~Hz}$ sine wave $(11.1 \mathrm{mV} \mathrm{rms})$ was superimposed on a command potential $(-70$ $\mathrm{mV}$ ) in whole-cell recording. We coated fire-polished thick-wall pipettes (3-7 M $\Omega$ ) with dental periphery wax and used a low level of bath solution (400 $\mu$ l per coverslip) to reduce the slow drift of the real $(R e)$ and imaginary ( Im) part of the admittance signals. The imaginary signal is linearly related to changes in membrane capacitance, whereas the real part of the admittance signal is contributed mainly by membrane conductance and access conductance (Neher and Marty, 1982; Zorec et al., 1991). During the measurements, the phase setting of the lock-in amplifier was adjusted to nullify the changes in the Re signal in response to a $100 \mathrm{fF}$ calibration steps. For the frequencies of the sine wave stimulation used (up to $\sim 20$ $\mathrm{kHz}$ ), the phase determination by the capacitance dithering provides a suitable calibration value (Debus and Lindau, 2000). The criteria of correct phase setting were as described previously (Neher and Marty, 1982; Zorec et al., 1991; Henkel et al., 2000). Signals from the lock-in amplifier ( $R e$ and $I m$ part of admittance signals were low-pass filtered at 100 to 1 $\mathrm{kHz},-3 \mathrm{~dB}$, two-pole Bessel), together with the DC current (low-pass filtered at $10 \mathrm{~Hz},-3 \mathrm{~dB}$, two-pole Bessel), unfiltered current and voltage were digitized at $10 \mathrm{kHz}$ (DIGIDATA 1322A 16-bit data acquisition system and the CLAMPFIT 9.2 software suite; Molecular Devices). Signals were additionally filtered by the filter options available with the CLAMPFIT 9.2 software.

When a fluorescent cell was identified under the microscope, we obtained a gigaseal whole-cell recording and read the resting membrane capacitance from the dials of the patch-clamp amplifier. After the phase adjustment (Fig. $1 \mathrm{~A}$ ), a series of $100 \mathrm{~ms}$ depolarizing voltage pulses in 10 $\mathrm{mV}$ increments was applied from the holding potential $(-70 \mathrm{mV})$. This voltage series was repeated 10 times with a $100 \mathrm{~ms}$ interval, and responses 
were averaged to reduce the noise level. For Figure $5 C$, a single voltage series was used.

Secretory responses were measured by determining the change in amplitude of the Im signal, proportional to the membrane capacitance $\left(C_{\mathrm{m}}\right)$, recorded before and after each pulse. We measured the average amplitude value of a $50 \mathrm{~ms}$ signal epoch starting $60 \mathrm{~ms}$ before the voltage pulse and a $50 \mathrm{~ms}$ signal epoch starting $10 \mathrm{~ms}$ after the end of the voltage pulse (Fig. $1 \mathrm{~B}$, middle trace, bars). The change in average capacitance was measured for each cell and these measurements were averaged. These epochs were additionally filtered by a digital Gaussian filter (Clampfit facility, low pass, $100 \mathrm{~Hz}$ ). Close inspection of the middle trace of Figure $1 B$ shows that, after the application of the voltage pulse, the amplitude of the averaged $I m$ trace, representing changes in $C_{\mathrm{m}}$, increased by $\sim 3 \mathrm{fF}$, without a correlated change in the Re part of the admittance signal, which reflects changes in membrane and access conductance. To insure that the voltage protocol application did not alter the phase setting, we repeated the phase adjustment after the voltage series (Fig. 1C). We also readjusted the phase after any solution changes to the recording chamber. All recordings were obtained at room temperature $\left(\sim 20^{\circ} \mathrm{C}\right)$.

All statistics are in the form of mean \pm SEM, unless otherwise stated. Statistical significance between averages was tested with a oneway ANOVA with Tukey's multiple-comparison test (GraphPad Prism, version 5).

\section{Results}

Acutely isolated taste cells have an ovoid to elongated spindle or fusiform shape with a maximal diameter of 3-10 $\mu \mathrm{m}$ and a length of 15-30 $\mu \mathrm{m}$ (Fig. 2A) (Romanov et al., 2007), which appears slightly smaller compared with electron micrographs published previously (Kinnamon et al., 1988; Royer and Kinnamon, 1988). Membrane capacitance $\left(C_{\mathrm{m}}\right)$ is a parameter proportional to membrane surface area (Neher and Marty, 1982) and considering a specific membrane capacitance of $5 \mathrm{fF} / \mu \mathrm{m}^{2}\left(=0.5 \mu \mathrm{F} / \mathrm{cm}^{2}\right)$ (Solsona et al., 1998) and assuming a cylindrical shape, an estimate of resting $C_{\mathrm{m}}$ from 1 to $8 \mathrm{pF}$ is expected in taste cells. Measurements on 75 cells revealed a resting $C_{\mathrm{m}}$ of $3.42 \pm 0.18 \mathrm{pF}$ (mean $\pm \mathrm{SEM}$ ), consistent with values reported previously (Bigiani, 2001). Resting $C_{\mathrm{m}}$ of type I cells, identified electrophysiologically (Fig. 2B-D) (Medler et al., 2003; Romanov and Kolesnikov, 2006), was $4.25 \pm 0.34 \mathrm{pF}(n=19)$. Type III cells, identified by green fluorescence of GAD67-GFP mice (Fig. 2 A) (DeFazio et al., 2006; Tomchik et al., 2007), had a resting capacitance of $2.60 \pm$ $0.12 \mathrm{pF}(n=37)$, whereas type II cells, identified by the green fluorescence of TRPM5-GFP mice and/or by the profile of voltage-activated inward currents (Fig. $2 B-D$ ) (Medler et al., 2003; Clapp et al., 2006), exhibited a resting capacitance of $4.21 \pm$ $0.46 \mathrm{pF}(n=19)$. Larger resting $C_{\mathrm{m}}$ of type I and type II taste cells $(p<0.001)$ compared with type III cells is consistent with their morphology (Royer and Kinnamon, 1994). Type I cells possess membranous extensions that envelop other taste cell types (Pumplin et al., 1997), contributing to their relatively high $C_{\mathrm{m}}$ for their apparent size.

To detect voltage-induced surface area changes monitored as $C_{\mathrm{m}}$ in the femtofarad range and to monitor the voltage-activated currents, we applied a series of nine depolarizing pulses (Fig. $3 \mathrm{~A}$ ) averaged over 10 cycles (to reduce noise) to determine whether the cell exhibited voltage-activated currents and showed concomitant changes in $C_{\mathrm{m}}$. Figure $3 B$ shows representative responses to the averaged series of voltage pulses in the three types of taste cells. Note that, at the highest voltage pulse amplitudes, significant increases in $C_{\mathrm{m}}$ are recorded in type III cells (Fig. $3 B$, top trace). In contrast, in type II (Fig. $3 B$, middle trace) and in type I (Fig. $3 B$, bottom trace) cells, such changes were not observed. Average changes in $C_{\mathrm{m}}$ (Fig. $3 C$ ), measured before and after each voltage pulse, show that only in type III cells voltage-

A
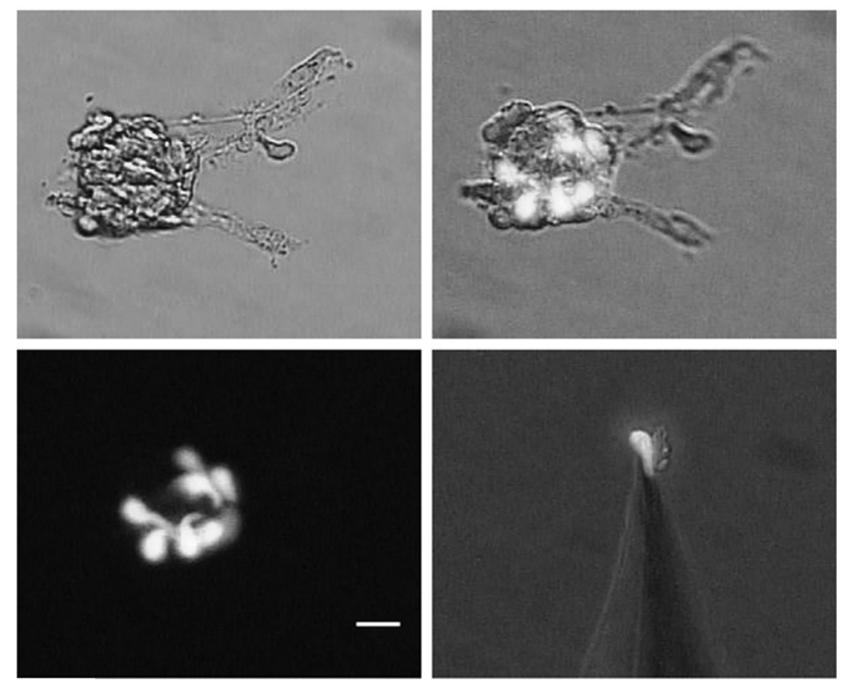

B

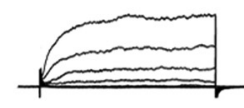

Type I

C

$100 \mathrm{pA}$ $20 \mathrm{~ms}$

$\mathrm{D}$
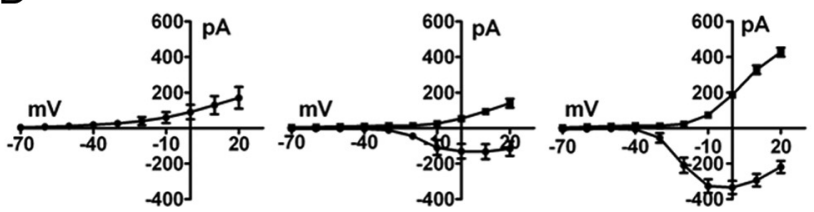

Figure 2. Optical and electrophysiological identification of taste cell type. $A$ illustrates photomicrographs of circumvallate taste buds and a single isolated taste cell, isolated from a GAD67-GFP mouse, attached to a patch pipette. GFP-labeled cells are type III taste cells. Similarly, type II taste cells could be identified by GFP fluorescence from TrpM5-GFP mice (data not shown). Scale bar, $20 \mu \mathrm{m}$. B illustrates typical current profiles of type I, type II, and type III taste cells in Tyrode's. C, Although both type II and type III taste cells have voltage-gated $\mathrm{Na}^{+}$ currents in response to membrane depolarization, only type III taste cells have voltage-gated currents in $\mathrm{Ba}^{2+}$ Tyrode's (with $\mathrm{Na}^{+}$and $\mathrm{K}^{+}$currents blocked). D illustrates the averaged I/V curves for the voltage-gated $\mathrm{Na}^{+}$(circles) and $\mathrm{K}^{+}$(squares) currents in type I $(n=10)$, type II ( $n=12)$, and type III $(n=18)$ cells in Tyrode's. Voltage was stepped in $10 \mathrm{mV}$ increments from -60 to $+20 \mathrm{mV}$ from a holding potential of $-70 \mathrm{mV}$. Error bars represent SEM.

induced increases in $C_{\mathrm{m}}$ are present. In the other two cell types, voltage-induced changes in $C_{\mathrm{m}}$ are not significantly different from zero. Moreover, when capacitance changes were normalized to the resting $C_{\mathrm{m}}$ of each cell and represented as a percentage of resting $C_{\mathrm{m}}$, similar results were obtained (Table 1 ).

As shown in Figure $2 \mathrm{~B}$, high-voltage-activated $\mathrm{Ca}^{2+}$ currents, determined in the presence of extracellular $\mathrm{Ba}^{2+}$ (see Materials and Methods), are expressed in type III cells, consistent with previous reports (Medler et al., 2003; Romanov and Kolesnikov, 2006). A recent study demonstrated that the currents in the GAD67-GFP subset of type III cells are carried primarily by P/Qtype $\mathrm{Ca}^{2+}$ channels, since they are blocked by $\Omega$-agatoxin IVA (Roberts et al., 2009). We confirmed that the peak Ba ${ }^{2+}$ currents in our preparation are blocked by $\Omega$-agatoxin IVA (data not 
shown). Since the general $\mathrm{Ca}^{2+}$ channel blocker $\mathrm{Cd}^{2+}$ is more readily reversible in our preparation, we elected to use $\mathrm{Cd}^{2+}$ to determine the $\mathrm{Ca}^{2+}$ dependence of the changes in $C_{\mathrm{m}}$ in type III taste cells. Compared with the control (Fig. $4 B$ ), the application of $0.5 \mathrm{mM} \mathrm{Cd}^{2+}$ reduced the depolarization-induced $C_{\mathrm{m}}$ changes (Fig. $4 C$ ) and the effect was reversible (Fig. $4 D)$. The effect was significant $(p<0.05$; $n=5$ ), based on the average of voltageinduced responses in $C_{\mathrm{m}}$, determined from the last five voltage pulses in the series (Fig. 4E). Partial, rather than full, recovery is likely attributable to a timedependent amplitude reduction of voltageinduced responses in $C_{\mathrm{m}}$ under control conditions, as shown on Figure $4 F$, in which we observed a decline with a time constant of $\sim 8$ min.

To further test the role of $\mathrm{Ca}^{2+}$, we studied the relationship between voltageinduced increases in $C_{\mathrm{m}}$ and the amplitude of voltage-activated $\mathrm{Ba}^{2+}$ currents. After the recording of voltage-induced changes in $C_{\mathrm{m}}$ in type III cells (measured with $\mathrm{Ca}^{2+}$-containing Tyrode's), we then recorded the voltage-activated $\mathrm{Ba}^{2+}$ currents (Fig. $2 B$, right panel) in the same cells. Figure $5 A$ shows the relationship between the average amplitude of voltageactivated $\mathrm{Ba}^{2+}$ currents as a function of membrane potential. The threshold of activation of these currents is related to the increase in voltage-induced changes in $C_{\mathrm{m}}$, recorded in the same cells (Fig. $5 B$ ); however, the $C_{\mathrm{m}}$ change did not decrease at voltages at which the $\mathrm{Ba}^{2+}$ current begins to decrease. To determine whether the lack of decrease in the $C_{\mathrm{m}}$ at higher voltage steps was attributable to averaging 10 runs, which might lead to $\mathrm{Ca}^{2+}$

buildup, we recorded $C_{\mathrm{m}}$ changes in taste cells with a single voltage series. Although the $C_{\mathrm{m}}$ changes in these cells were more variable because of the lack of averaging, they showed a clear decrease in $C_{\mathrm{m}}$ at higher voltage steps, paralleling the decrease in $\mathrm{Ba}^{2+}$ current at the same voltage steps. These results corroborate and extend the results obtained with $\mathrm{Cd}^{2+}$ and are consistent with the hypothesis that type III taste cells exhibit $\mathrm{Ca}^{2+}$ associated voltage-dependent changes in $C_{\mathrm{m}}$, likely reflecting regulated exocytosis of transmitter.

\section{Discussion}

The aim of this study was to test whether taste cells exhibit depolarization-induced regulated exocytosis, consistent with the fusion of vesicle membrane with the plasma membrane, as monitored by patch-clamp membrane capacitance measurements (Neher and Marty, 1982). We show that a sequence of depolarizing stimuli in type III taste cells reliably evokes increases in $C_{\mathrm{m}}$ that are not observed in either type II or type I taste cells. Although the depolarization-evoked $C_{\mathrm{m}}$ responses in the taste cells are small compared with those of mammalian sensory receptors with ribbon synapses [i.e., $4-5 \mathrm{fF}$ in taste cells compared with
Table 1. Maximum values of $\Delta C_{m}$ normalized to individual cell resting capacitance, expressed as percentage max $\Delta C_{m}$

\begin{tabular}{llcr}
\hline & $\begin{array}{l}\text { Type III } \\
(n=18)\end{array}$ & $\begin{array}{l}\text { Type II } \\
(n=12)\end{array}$ & \multicolumn{1}{l}{$\begin{array}{l}\text { Type I } \\
(n=10)\end{array}$} \\
\hline Resting $C_{\mathrm{m}}$ (pF) & $2.47 \pm 0.17$ & $3.79 \pm 0.50$ & $4.06 \pm 0.57$ \\
$\operatorname{Max} \Delta C_{\mathrm{m}}$ at $+20 \mathrm{mV}$ (fF) & $3.67 \pm 0.59$ & $0.32 \pm 0.32$ & $0.16 \pm 0.73$ \\
$\% \operatorname{Max} \Delta C_{\mathrm{m}}$ at $+20 \mathrm{mV}$ & $0.16 \pm 0.03$ & $0.003 \pm 0.012$ & $0.012 \pm 0.03$
\end{tabular}

The cells included in this table represent only those cells whose change in $C_{m}$ were measured. The percentage max $\Delta C_{\mathrm{m}}$ of type III taste cells is significantly different ( $p<0.05$; one-way ANOVA with Tukey's multiple-comparison test) from both type I and type II taste cells. The percentage $\max \Delta C_{\mathrm{m}}$ values for type I and type II cells are not significantly different from each other.

30-40 fF for mouse vestibular hair cells (Dulon et al., 2009) and $>100 \mathrm{fF}$ for photoreceptors (Innocenti and Heidelberger, 2008)], the responses are robust and repeatable. This finding is consistent with the comparatively small synaptic area in taste cells compared with hair cells and photoreceptors (Royer and Kinnamon, 1988, 1994). Furthermore, capacitance changes in taste cells are likely to be $\mathrm{Ca}^{2+}$-dependent, involving the entry of $\mathrm{Ca}^{2+}$ through the voltage-activated $\mathrm{Ca}^{2+}$ channels. $C_{\mathrm{m}}$ responses were inhibited by the $\mathrm{Ca}^{2+}$ channel blocker $\mathrm{Cd}^{2+}$ and the threshold voltage for $C_{\mathrm{m}}$ 


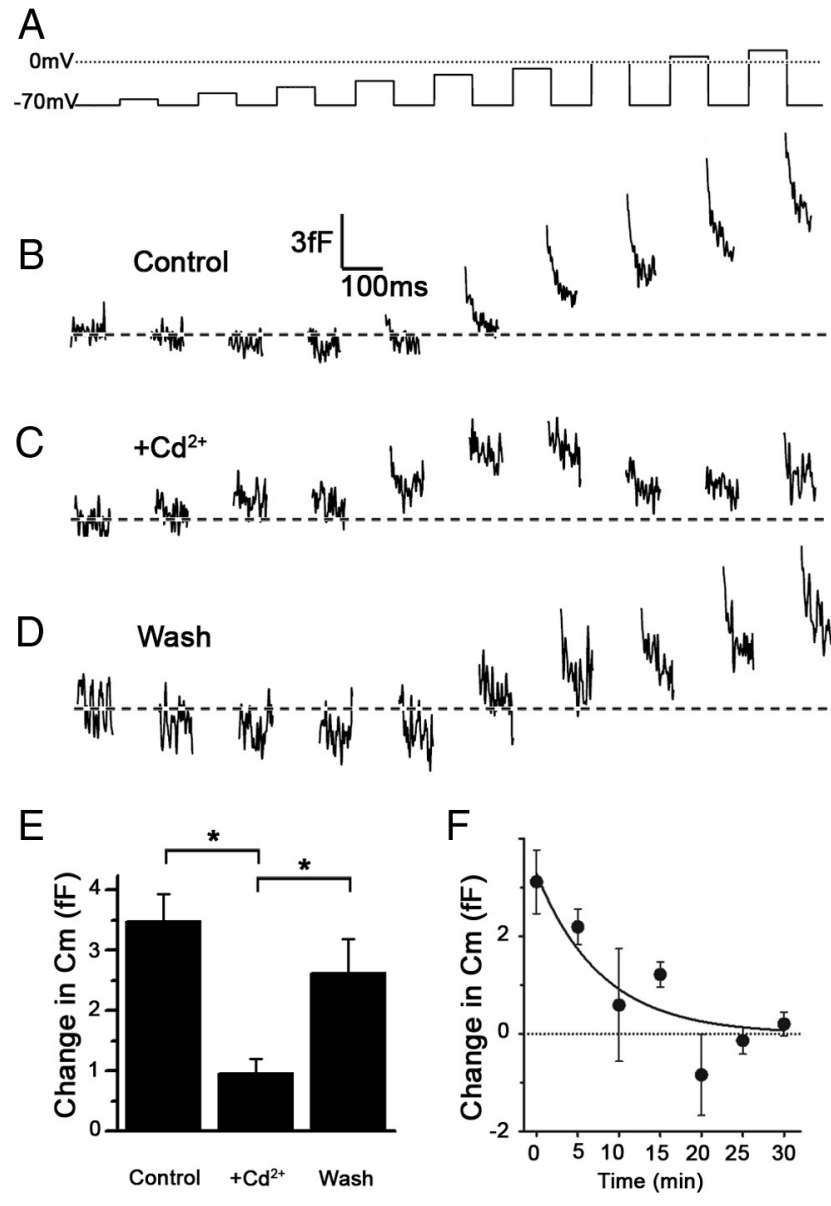

Figure 4. $\quad \mathrm{Cd}^{2+}$-mediated attenuation of voltage-induced changes in $C_{\mathrm{m}}$ in a type III taste cell. $\boldsymbol{A}$, The sequence of voltage pulses applied to the taste cell clamped at $-70 \mathrm{mV}$. $\boldsymbol{B}$, Control depolarization-induced changes in $C_{m}$, recorded before the application of $\mathrm{Cd}^{2+}$ Tyrode's solution. C, Depolarization-induced changes in $\mathrm{C}_{\mathrm{m}}$ recorded $3 \mathrm{~min}$ after the application of a Tyrode's solution containing $0.5 \mathrm{~mm} \mathrm{Cd}{ }^{2+}$. D, Recovery of depolarization-induced changes in $C_{\mathrm{m}}$ after 5 min wash of the cell with Tyrode's. The traces in $B-D$ were low-pass filtered ( $100 \mathrm{~Hz}$, Gaussian filter). $\boldsymbol{E}$, Average amplitude of depolarization-induced increases in $C_{m}$, determined from the last five voltage pulses $(-20$ to $+20 \mathrm{mV})$ on five cells was significantly reduced $(p<0.05)$ after the application of $\mathrm{Cd}^{2+}$. There was a significant $\left({ }^{*} p<0.05\right.$; one-way ANOVA with Tukey's multiple-comparison test) recovery after washout of the $\mathrm{Cd}^{2+}$ Tyrode's. $\boldsymbol{F}$, Time-dependent amplitude reduction of depolarization-induced $C_{\mathrm{m}}$ in type III taste cells ( $n=6$ cells). The voltage pulse protocol was applied to a single cell in 5 min intervals. The response in $C_{m}$ was averaged for the voltage pulses from -20 to $+20 \mathrm{mV}$. The line represents the best fit to the equation of the form: $C_{\mathrm{m}}(\mathrm{fF})=(3.28 \pm 0.63) \mathrm{e}^{(0.127 \pm 0.047)^{*} \text { time(min) }}$, yielding a time constant of the decay of $\sim 8 \mathrm{~min}$. Error bars represent SEM.

increases mirrored the threshold for voltage-dependent $\mathrm{Ba}^{2+}$ current activation. Furthermore, when a single voltage series was used to stimulate the taste cells, there was a clear decline in $C_{\mathrm{m}}$ at higher voltages at which the $\mathrm{Ba}^{2+}$ current is declining. It is interesting that there was no obvious linear relationship between $\mathrm{Ca}^{2+}$ current density and $C_{\mathrm{m}}$ change when 10 runs were averaged. Although membrane $C_{\mathrm{m}}$ peaked at the peak of the $\mathrm{Ba}^{2+}$ current, it did not decay with the decreasing $\mathrm{Ba}^{2+}$ current at high voltages. The lack of decrease of $C_{\mathrm{m}}$ at higher voltages may be attributable to a residual buildup of intracellular $\mathrm{Ca}^{2+}$, since the voltage pulses were separated by only $100 \mathrm{~ms}$ and the voltage series was averaged over 10 cycles. However, this rate of stimulation is physiological, since type III cells are highly electrically excitable and generate trains of action potentials to taste stimuli (Yoshida et al., 2009). Repetitive voltage steps, such as pairedpulse protocols, are commonly used to test the presence of facil-
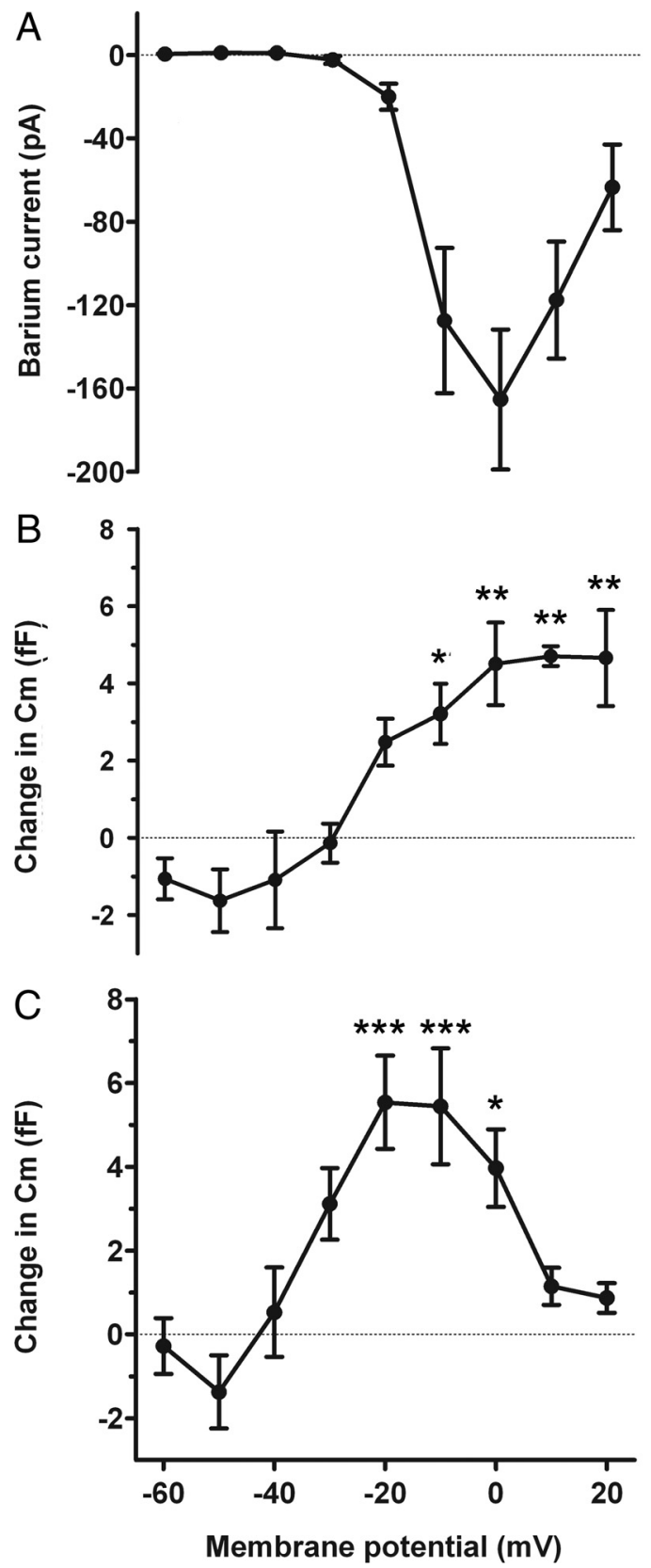

Figure 5. Relationship between the voltage pulse-induced calcium currents and the $C_{m}$ change. $A, \mathrm{Ba}^{2+}$ currents (determined in the presence of extracellular $\mathrm{Ba}^{2+}$ ) at different membrane potentials. $\boldsymbol{B}$, Changes in membrane capacitance $\left(C_{\mathrm{m}}\right)$ recorded before and after the pulse were measured at the same membrane potentials in $\mathrm{Ca}^{2+}$-containing Tyrode's. Cells were held at $-70 \mathrm{mV}$ before stimulating them with the voltage protocol. Each value of $C_{m}$ represents the average value obtained from 10 runs ( $n=4$ cells). $C$, Changes in $C_{m}$ recorded after a single voltage pulse series in a different set of taste cells $\left(n=10\right.$ cells). $\mathrm{Ba}^{2+}$ currents are combined in $A$ from both sets of cells. Error bars represent SEM. The asterisks adjacent to data points show the level of significance $\left({ }^{* * *} p<0.001,{ }^{* *} p<0.01,{ }^{*} p<0.05\right.$, in comparison with the response to $-60 \mathrm{mV}$; one-way ANOVA with Tukey's multiple-comparison test).

itation of current amplitudes. The augmentation of responses is thought to be attributable to a buildup of $\mathrm{Ca}^{2+}$.

Type III taste cells contain two classes of vesicles: small clear synaptic vesicles with a diameter of $40-70 \mathrm{~nm}$ and vesicles with a dense core with a diameter of 90-120 nm (Royer and Kinnamon, 1994). Considering that type III cells in mouse form on average two synapses with the afferent nerve, and that each presynaptic site consists of $\sim 250$ small clear vesicles, the fusion of all these 
vesicles with the plasma membrane on stimulation will result in a surface area increase of the taste cell of $\sim 4 \mu \mathrm{m}^{2}$, or an equivalent of $20 \mathrm{fF}$. Furthermore, it was shown that there are approximately five dense-core vesicles per slice of $250 \mathrm{~nm}$ thickness in type III taste cells [Royer and Kinnamon (1994), their Fig. 5]. Considering that a synapse consists of five sections (Royer and Kinnamon, 1994), each synapse will contain $\sim 25$ dense-core vesicles. Assuming that all dense-core vesicles fuse with the plasma membrane on stimulation, a membrane surface area of $\sim 1 \mu \mathrm{m}^{2}$, or an equivalent of $5 \mathrm{fF}$ is expected. These data, combined with our $C_{\mathrm{m}}$ measurements, suggest that $\sim 20 \%$ of the vesicles are released in response to each depolarizing stimulus. Since this number is much lower than that observed with sensory cells with ribbon synapses that rely on fast communication with sensory afferents (Innocenti and Heidelberger, 2008; Dulon et al., 2009), it suggests that the readily releasable pool of vesicles in type III taste cells is much lower. Alternatively, the relatively small increase in $C_{\mathrm{m}}$ may also be attributable to the ongoing endocytosis. A very small decline in $C_{\mathrm{m}}$ was observed during the first few voltage steps, which may reflect background endocytosis, especially since the data were averaged over a 10 pulse series (Figs. $3 B$, top trace; $4 B$, top and bottom traces). Moreover, at higher amplitude voltage steps, a more rapid decline in $C_{\mathrm{m}}$ was observed, which may reflect a more rapid component of endocytosis, observed in other sensory cells (Matthews, 1996). However, the observed slow decline of $C_{\mathrm{m}}$ was much slower that the voltage pulse duration, which should minimally affect the measured increases in $C_{\mathrm{m}}$. However, it cannot be ruled out completely that the voltage-induced steps in $C_{\mathrm{m}}$ are somehow underestimated by the slow decline in $C_{\mathrm{m}}$ because of slow endocytosis.

An important question that remains is the identity of the transmitter(s) that are released by each type of vesicle. Both serotonin (Y. J. Huang et al., 2005; Y. A. Huang et al., 2009) and norepinephrine (Y. A. Huang et al., 2008) are released from type III taste cells, and both likely involve dense-core vesicles. The transmitter(s) contained in the small clear vesicles are not known, but could be GABA, since type III cells express GAD67 (DeFazio et al., 2006). Additional studies will be required to determine whether type III cells release GABA in response to depolarization.

The lack of depolarization-induced $C_{\mathrm{m}}$ changes in the other types of taste cells is noteworthy. Type I cells are similar to astrocytes (Lawton et al., 2000; Bartel et al., 2006) in expressing proteins for uptake and degradation of transmitters. Unlike astrocytes, type I taste cells contain abundant, membrane-associated dense granules in the apical region supposedly released to contribute to the dense substance in the taste pore (Takeda and Hoshino, 1975). Recent data also suggest that type I cells may play a role in transduction. They express the amiloride-sensitive $\mathrm{Na}^{+}$channel $\mathrm{ENaC}$, suggesting that type I cells may be the primary transducer of amiloride-sensitive salt taste (Vandenbeuch et al., 2008). How salt taste information is transmitted from type I taste cells to the nervous system or neighboring cells is unclear. These cells do not form morphologically identifiable synapses with nerve fibers. Our data indicate that depolarization does not result in release of either vesicles or dense granules.

Type II cells release ATP via hemichannels composed of pannexin-1 and/or connexin subunits (Y. J. Huang et al., 2007; Romanov et al., 2007; Dando and Roper, 2009) to activate P2X receptors on the afferent nerve fibers (Finger et al., 2005). However, type II cells also contain some components of synaptic machinery, including synaptobrevin-2 (Yang et al., 2004) and synaptophysin (Asano-Miyoshi et al., 2009). In addition, type II cells express several peptide transmitters, including GLP-1 (glucagon-like peptide I) (Shin et al., 2008); NPY (neuropeptide Y), CCK (cholecystokinin), and VIP (vasoactive intestinal peptide) (Shen et al., 2005; Zhao et al., 2005; Herness and Zhao, 2009); and galanin (Seta et al., 2006). Furthermore, many type II cells express choline acetyltransferase and vesicular acetylcholine transporter (Ogura and Lin, 2005; Ogura et al., 2007), suggesting ACh may also be released. If and how these transmitter candidates are released remains in question. Romanov et al. (2007) demonstrated that ATP is released from type II cells in response to depolarizing voltage steps; however, our data appear to rule out voltage-regulated exocytosis. Type II cells use $\mathrm{IP}_{3}$-mediated release of $\mathrm{Ca}^{2+}$ from intracellular stores in the transduction of bitter, sweet, and umami taste stimuli (Zhang et al., 2003), and this may provide sufficient intracellular $\mathrm{Ca}^{2+}$ to evoke vesicular exocytosis. Additional experiments will be required to test this possibility.

\section{References}

Asano-Miyoshi M, Hamamichi R, Emori Y (2009) Synaptophysin as a probable component of neurotransmission occurring in taste receptor cells. J Mol Histol 40:59-70.

Bartel DL, Sullivan SL, Lavoie EG, Sévigny J, Finger TE (2006) Nucleoside triphosphate diphosphohydrolase-2 is the ecto-ATPase of type I cells in taste buds. J Comp Neurol 497:1-12.

Béhé P, DeSimone JA, Avenet P, Lindemann B (1990) Membrane currents in taste cells of the rat fungiform papilla. Evidence for two types of $\mathrm{Ca}$ currents and inhibition of $\mathrm{K}$ currents by saccharin. J Gen Physiol 96:1061-1084.

Bigiani A (2001) Mouse taste cells with glialike membrane properties. J Neurophysiol 85:1552-1560.

Chandrashekar J, Hoon MA, Ryba NJ, Zuker CS (2006) The receptors and cells for mammalian taste. Nature 444:288-294.

Clapp TR, Yang R, Stoick CL, Kinnamon SC, Kinnamon JC (2004) Morphologic characterization of rat taste receptor cells that express components of the phospholipase $\mathrm{C}$ signaling pathway. J Comp Neurol 468:311-321.

Clapp TR, Medler KF, Damak S, Margolskee RF, Kinnamon SC (2006) Mouse taste cells with $\mathrm{G}$ protein-coupled taste receptors lack voltagegated calcium channels and SNAP-25. BMC Biol 4:7.

Dando R, Roper SD (2009) Cell-to-cell communication in intact taste buds through ATP signalling from pannexin 1 gap junction hemichannels. J Physiol 587:5899-5906.

Debus K, Lindau M (2000) Resolution of patch capacitance recordings and of fusion pore conductances in small vesicles. Biophys J 78:2983-2997.

DeFazio RA, Dvoryanchikov G, Maruyama Y, Kim JW, Pereira E, Roper SD, Chaudhari N (2006) Separate populations of receptor cells and presynaptic cells in mouse taste buds. J Neurosci 26:3971-3980.

Dulon D, Safieddine S, Jones SM, Petit C (2009) Otoferlin is critical for a highly sensitive and linear calcium-dependent exocytosis at vestibular hair cell ribbon synapses. J Neurosci 29:10474-10487.

Finger TE, Danilova V, Barrows J, Bartel DL, Vigers AJ, Stone L, Hellekant G, Kinnamon SC (2005) ATP signaling is crucial for communication from taste buds to gustatory nerves. Science 310:1495-1499.

Henkel AW, Meiri H, Horstmann H, Lindau M, Almers W (2000) Rhythmic opening and closing of vesicles during constitutive exo- and endocytosis in chromaffin cells. EMBO J 19:84-93.

Herness S, Zhao FL (2009) The neuropeptides CCK and NPY and the changing view of cell-to-cell communication in the taste bud. Physiol Behav 97:581-591.

Huang YA, Maruyama Y, Roper SD (2008) Norepinephrine is coreleased with serotonin in mouse taste buds. J Neurosci 28:13088-13093.

Huang YA, Dando R, Roper SD (2009) Autocrine and paracrine roles for ATP and serotonin in mouse taste buds. J Neurosci 29:13909-13918.

Huang YJ, Maruyama Y, Lu KS, Pereira E, Plonsky I, Baur JE, Wu D, Roper SD (2005) Mouse taste buds use serotonin as a neurotransmitter. J Neurosci 25:843-847.

Huang YJ, Maruyama Y, Dvoryanchikov G, Pereira E, Chaudhari N, Roper SD (2007) The role of pannexin 1 hemichannels in ATP release and cell-cell communication in mouse taste buds. Proc Natl Acad Sci U S A 104:6436-6441. 
Innocenti B, Heidelberger R (2008) Mechanisms contributing to tonic release at the cone photoreceptor ribbon synapse. J Neurophysiol 99:25-36.

Iwatsuki K, Ichikawa R, Hiasa M, Moriyama Y, Torii K, Uneyama H (2009) Identification of the vesicular nucleotide transporter (VNUT) in taste cells. Biochem Biophys Res Commun 388:1-5.

Kinnamon JC, Sherman TA, Roper SD (1988) Ultrastructure of mouse vallate taste buds: III. Patterns of synaptic connectivity. J Comp Neurol 270:1-10, 56-57.

Lawton DM, Furness DN, Lindemann B, Hackney CM (2000) Localization of the glutamate-aspartate transporter, GLAST, in rat taste buds. Eur J Neurosci 12:3163-3171.

Marty A, Neher E (1983) Tight-seal whole-cell recording. In: Single-channel recording (Sakmann B, Neher E, eds), pp 107-113. New York: Plenum.

Matthews G (1996) Synaptic exocytosis and endocytosis: capacitance measurements. Curr Opin Neurobiol 6:358-364.

Medler KF, Margolskee RF, Kinnamon SC (2003) Electrophysiological characterization of voltage-gated currents in defined taste cell types of mice. J Neurosci 23:2608-2617.

Neher E, Marty A (1982) Discrete changes of cell membrane capacitance observed under conditions of enhanced secretion in bovine adrenal chromaffin cells. Proc Natl Acad Sci U S A 79:6712-6716.

Ogura T, Lin W (2005) Acetylcholine and acetylcholine receptors in taste receptor cells. Chem Senses 30 [Suppl 1]:i41.

Ogura T, Margolskee RF, Tallini YN, Shui B, Kotlikoff MI, Lin W (2007) Immuno-localization of vesicular acetylcholine transporter in mouse taste cells and adjacent nerve fibers: indication of acetylcholine release. Cell Tissue Res 330:17-28.

Pérez CA, Huang L, Rong M, Kozak JA, Preuss AK, Zhang H, Max M, Margolskee RF (2002) A transient receptor potential channel expressed in taste receptor cells. Nat Neurosci 5:1169-1176.

Pumplin DW, Yu C, Smith DV (1997) Light and dark cells of rat vallate taste buds are morphologically distinct cell types. J Comp Neurol 378:389-410.

Roberts CD, Dvoryanchikov G, Roper SD, Chaudhari N (2009) Interaction between the second messengers cAMP and $\mathrm{Ca}^{2+}$ in mouse presynaptic taste cells. J Physiol 587:1657-1668.

Romanov RA, Kolesnikov SS (2006) Electrophysiologically identified subpopulations of taste bud cells. Neurosci Lett 395:249-254.

Romanov RA, Rogachevskaja OA, Bystrova MF, Jiang P, Margolskee RF, Kolesnikov SS (2007) Afferent neurotransmission mediated by hemichannels in mammalian taste cells. EMBO J 26:657-667.

Royer SM, Kinnamon JC (1988) Ultrastructure of mouse foliate taste buds: synaptic and nonsynaptic interactions between taste cells and nerve fibers. J Comp Neurol 270:11-24, 58-59.

Royer SM, Kinnamon JC (1994) Application of serial sectioning and three- dimensional reconstruction to the study of taste bud ultrastructure and organization. Microsc Res Tech 29:381-407.

Seta Y, Kataoka S, Toyono T, Toyoshima K (2006) Expression of galanin and the galanin receptor in rat taste buds. Arch Histol Cytol 69:273-280

Shen T, Kaya N, Zhao FL, Lu SG, Cao Y, Herness S (2005) Co-expression patterns of the neuropeptides vasoactive intestinal peptide and cholecystokinin with the transduction molecules alpha-gustducin and T1R2 in rat taste receptor cells. Neuroscience 130:229-238.

Shin YK, Martin B, Golden E, Dotson CD, Maudsley S, Kim W, Jang HJ, Mattson MP, Drucker DJ, Egan JM, Munger SD (2008) Modulation of taste sensitivity by GLP-1 signaling. J Neurochem 106:455-463.

Solsona C, Innocenti B, Fernández JM (1998) Regulation of exocytotic fusion by cell inflation. Biophys J 74:1061-1073.

Takeda M, Hoshino T (1975) Fine structure of taste buds in the rat. Arch Histol Jpn 37:395-413.

Tomchik SM, Berg S, Kim JW, Chaudhari N, Roper SD (2007) Breadth of tuning and taste coding in mammalian taste buds. J Neurosci 27:10840-10848.

Vandenbeuch A, Clapp TR, Kinnamon SC (2008) Amiloride-sensitive channels in type I fungiform taste cells in mouse. BMC Neurosci 9:1.

Yang R, Crowley HH, Rock ME, Kinnamon JC (2000) Taste cells with synapses in rat circumvallate papillae display SNAP-25-like immunoreactivity. J Comp Neurol 424:205-215.

Yang R, Stoick CL, Kinnamon JC (2004) Synaptobrevin-2-like immunoreactivity is associated with vesicles at synapses in rat circumvallate taste buds. J Comp Neurol 471:59-71.

Yee CL, Yang R, Böttger B, Finger TE, Kinnamon JC (2001) “Type III” cells of rat taste buds: immunohistochemical and ultrastructural studies of neuron-specific enolase, protein gene product 9.5, and serotonin. J Comp Neurol 440:97-108.

Yoshida R, Shigemura N, Sanematsu K, Yasumatsu K, Ishizuka S, Ninomiya Y (2006) Taste responsiveness of fungiform taste cells with action potentials. J Neurophysiol 96:3088-3095.

Yoshida R, Miyauchi A, Yasuo T, Jyotaki M, Murata Y, Yasumatsu K, Shigemura N, Yanagawa Y, Obata K, Ueno H, Margolskee RF, Ninomiya Y (2009) Discrimination of taste qualities among mouse fungiform taste bud cells. J Physiol 587:4425-4439.

Zhang Y, Hoon MA, Chandrashekar J, Mueller KL, Cook B, Wu D, Zuker CS, Ryba NJ (2003) Coding of sweet, bitter, and umami tastes: different receptor cells sharing similar signaling pathways. Cell 112:293-301.

Zhao FL, Shen T, Kaya N, Lu SG, Cao Y, Herness S (2005) Expression, physiological action, and coexpression patterns of neuropeptide $\mathrm{Y}$ in rat taste-bud cells. Proc Natl Acad Sci U S A 102:11100-11105.

Zorec R, Henigman F, Mason WT, Kordas M (1991) Electrophysiological study of hormone secretion by single adenohypophyseal cells. Methods Neurosci 4:194-210 